\title{
PENINGKATAN PEMAHAMAN SISWA MATA PELAJARAN PKn TENTANG SISTEM PEMERINTAHAN MELALUI METODE M2M (MIND MAPPING) KELAS IV MI MAMBAUL ULUM TEGALGONDO KARANGPLOSO MALANG
}

\author{
Devi Afriyuni Yonanda ${ }^{1)}$ \\ deviyonanda1990@gmail.com
}

\begin{abstract}
ABSTRAK
Berdasarkan pengalaman lapangan, pemahaman materi yang diterima oleh siswa pada pembelajaran PKn masih belum optimal, penelitian ini menggunakan metode Mind Mapping. Tujuan dari penelitian adalah untuk mengetahui peningkatan pemahaman siswa mata pelajaran PKn tentang sistem pemerintahan kelas IV MI Mambaul Ulum Karangpoloso Tegalgondo Malang.Penelitian ini menggunakan rancangan Penelitian Tindakan Kelas (PTK) yang dilaksanakan dalam dua siklus. Setiap siklus terdiri dari refleksi awal, perencanaan, tindakan/observer, dan refleksi akhir. Lokasi dan subyek penelitian adalah siswa kelas IV MI Mambaul Ulum Karangploso Tegalgondo Malang yang dilaksanakan pada bulan Januari-Maret 2012 Semester Genap Tahun Pelajaran 2011/2012. Hasil penelitian menujukkan bahwa penerapan metode Mind Mapping dengan media bagan peta konsep pada siswa kelas IV MI Mambaul Ulum Karangploso Tegalgondo Malang, diperoleh $82 \%$ sudah memenuhi KKM yang ditentukan. Yang diperoleh melalui metode Mind Mapping dengan pembuatan bagan peta konsep dan evaluasi berupa soal latihan pada akhir pembelajaran. Ketuntasan pemahaman yang dicapai pada siklus I, dan 11 mengalami peningkatan yang sangat signifikan sehingga sangat berpengaruh pada nilai akhir yang didapat oleh siswa.Saran yang dapat diajukan untuk pembelajaran selanjutnya adalah: 1). Guru harus lebih mempersiapkan pembelajaran yang akan dilakukan melalui pemilihan materi yang sesuai dengan metode Mind Mappingdalam proses belajar mengajar pelajaran PKn, sehingga hasil pemahaman siswa akan meningkat dan memperoleh hasil yang maksimal sesuai dengan KKM yang diharapkan.
\end{abstract}

Kata Kunci : Metode Mind Mapping, Pemahaman siswa

\footnotetext{
${ }^{1}$ Penulis adalah dosen tetap Prodi PGSD Fakultas Pendidikan Dasar dan Menengah Universitas Majalengka
} 


\section{PENDAHULUAN}

Perkembangan Ilmu Pengetahuan dan Teknologi (IPTEK) di era globalisasi sesuai Sumber Daya Manusia (SDM) yang berkualitas. Dengan begitu perkembangan Ilmu Pengetahuan dan Teknologi (IPTEK) yang ada dapat dikuasai, dimanfaatkan semaksimal mungkin dan dapat dikembangkan menjadi lebih baik. Pendidikan merupakan sarana dan wahana yang sangat baik di dalam pembinaan generasi yang akan datang, oleh karena itu pendidikan perlu mendapat perhatian, penanganan dan prioritas secara baik oleh pemerintah, keluarga dan pengelola pendidikan.

Pendidikan merupakan masalah yang sangat menarik untuk dibahas karena melalui usaha pendidikan diharapkan tujuan pendidikan akan segara tercapai. Salah satu tujuan Pendidikan Nasional yang ingin dicapai dalam pembangunan sebagaimana tercantum dalam Undang-Undang No.20 tahun 2003 tentang sistem pendidikan nasional yang menyatakan bahwa: Pendidikan nasional berfungsi mengembangkan kemampuan dan membentuk watak serta peradaban bangsa yang bermanfaat dalam rangka mencerdaskan kehidupan bangsa, bertujuan untuk berkembang potensi peserta didik agar menjadi manusia beriman dan bertaqwa kepada Tuhan Yang Maha Esa, berakhlak mulia, sehat, berilmu, cakap, kreatif, mandiri dan menjadi warga Negara yang demokratis dan bertanggung jawab.

Oleh karena itu guru harusOleh karena itu guru harusdapat menerapkan dalam kegiatan pembelajaran di sekolahsecara maksimal,melalui pembelajaran PKn yang telah diberikan di sekolah untuk mewujudkan manusia yang berakhlak mulia.

Guruselaku orang yang paling bertanggung jawab di dalam pendidikan formal di sekolah, seharusnya selalu aktif dan kreatif dalam berusaha meningkatkan hasil belajar anak didiknya. Guru harus selalu mencari alternatif pembelajaran yang sesuai dengan materi yang akan disampaikan kepada siswa, dengan harapan siswa akan merasa bersemangat dalam mengikuti kegiatan belajar di sekolah maupun dalam belajar di rumah.

Peningkatan pembelajaran PKn sudah di lakukan guru secara terus-menerus dengan berbagai metode telah di lakukan oleh guru tetapi masih ada siswa yang tertinggal dalam pembelajaran karena kurangnya pemahaman materi yang diberikan oleh guru. Oleh karena itu guru harus merancang pembelajaran yang lebih baik agar pembelajaran di kelas dapat tercapai sesuai dengan tujuan pendidikan yang di harapkan. Guru harus bisa merancang pembelajaran yang menarik, sehingga materi yang akan di sampaikan dapat diterima oleh peserta didik. Banyak faktor-faktor yang dapat mempengaruhi sulitnya pemahaman yang di alami oleh siswa salah satunya adalah kurangnya konsentrasi pada saat pembelajaran berlangsung dan kurangnya motivasi siswa untuk giat belajar. Karena perbedaanya latar belakang siswa baik dari lingkungan keluarga maupun lingkunan masyarakat. Rendahnya pemahaman yang diterima oleh siswa dapat mengakibatkan kurangnya penguasaan konsep untuk jenjang berikutnya, hasil yang diperoleh siswa ratarata adalah $65 \%$, sehingga masih banyak siswa yang kurang mencapai tujuan pembelajaran yang diharapkan.

Ilustrasi di atas menggambarkan yang sedang terjadi di kelas IV MI Mambaul Ulum TegalgondoKarangploso Malang, banyak sekali siswa kurang memahami tentang sistem pemerintahan, siswa masih kesulitan dalam mengenal sistem pemerintahan yang ada di Indonesia dan jika dengan menghafal siswa menjadi mudah lupa. Di lihat dari hasil prestasi yang di peroleh siswa untuk mencapai kriteria ketuntasan minimal (KKM) yang telah di 
tentukan oleh guru yaitu $70 \%$, masih banyak siswa yang kurang mencapai rata-rata nilai yang telah di tentukan oleh guru. Hal ini jangan sampai terjadi dalam pembelajaran karena guru telah merencanakan pembelajaran yang menarik, inovatif dan menyenangkan. Dengan melibatkan siswa untuk berperan aktif dalam pembelajaran. Karena masa anak usia sekolah dasar adalah masa bermain, maka guru harus menciptakan berbagai metode untuk meningkatkan pemahaman siswa dalam pembelajaran di kelas.

Peningkatan pemahaman siswa dalam pembelajaran dan tidak menyebabkan kesalahan konsep pada siswa untuk jenjang yang lebih tinggi dapat dilakukan dengan cara guru harus dapat menciptakan berbagai metode untuk meningkatkan pemahaman siswa dalam pelajaran PKn dan dapat diterima oleh siswa dengan hasil prestasi yang maksimal, melaui metode Mind Mappingyang dapat membangkitkan kreatifitas siswa sesuai dengan kemampuan yang di miliki oleh siswa.

Peneliti berusaha untuk merefleksikan dan berupaya untuk mencari pemecahan masalah tersebut agar pemahaman yang di capai oleh siswa dapat meningkatkan pemahaman siswa dengan melalui metode Mind Mappingyang dikenal dengan peta pemikiran. Di mana dengan menggunakan metode tersebut akan memotivasi siswa dalam memahami materi tersebut serta meningkatkan konsentrasi siswa pada saat kegiatan belajar mengajar. Dan dapat mencapai Kriteria Ketuntasan Minimal (KKM) yang telah di tentukan oleh guru. Berdasarkan uraian di atas maka peneliti mengambil judul berupa"Peningkatan Pemahaman Siswa Mata Pelajaran PKN Tentang Sistem Pemerintahan Melalui Metode M2M (Mind Mapping) Kelas IV MI Mambaul Ulum Tegalgondo Karangploso Malang”.
Mind Mapping

MenurutMichael Gelb dalam Buzan (dalam Kurniawati 2010:17-18):Mind Mapping diartikan sistem revolusioner dalam perencanaan dan pembuatan catatan yang telah mengubah hidup jutaan orang di seluruh dunia. Pembuatan Mind Mapping didasarkan pada cara kerja alamiah otak dan mampu menyalakan percikan kreatifitas dalam otak karena melibatkan kedua belahan otak kita.

Menurut Porter \& Hernacki (dalam Kurniawati 2010:16;17):Mind Mapping juga dapat disebut dengan peta pemikiran. Mind Mapping menggunakan pengingatvisual dan sensorik dalam suatu pola dari ide-ide yangberkaitan. Peta pikiran atau Mind Mapping pada dasarnya menggunakan citra visual dan prasarana grafis lainnya untuk membentuk kesan pada otak.

Metode Mind Mapping adalah metode baru untuk mencatat yang bekerjanya disesuaikan dengan bekerjanya dua belah otak (otak kiri dan otak kanan). Metode ini mengajarkan untuk mencatat tidak hanya menggunakan gambar atau warna. Tony Buzan (dalam Kurniawati 2010:17) mengemukakan "yourbrain is like a sleeping giant, hal itu disebabkan $99 \%$ kehebatan otak manusia belum dimanfaatkan secara optimal.

$$
\begin{gathered}
\text { Tabel Penggunaan Otak } \\
\text { pada Mind Mapping }
\end{gathered}
$$

\begin{tabular}{|l|c|}
\hline \multicolumn{1}{|c|}{ Otak kiri } & Otak kanan \\
\hline 1. Tulisan & $\begin{array}{c}\text { Warna } \\
\text { Gambar } \\
\text { Dimensi }\end{array}$ \\
$\begin{array}{l}\text { 2. Urutan penulisan } \\
\begin{array}{l}\text { 3. Hubungan antar } \\
\text { kata }\end{array}\end{array}$ \\
\hline
\end{tabular}

Mind Mapping adalah cara mencatat yang kreatif, efektif dan secara harfiah akan memetakan pikiran-pikiran Mind Mapping juga merupakan peta rute yang memudahkan 
ingatan dan memungkinkan untuk menyusun fakta dan pikiran, dengan demikian cara kerja alami otak dilibatkan sejak awal. Ini berarti mengingat informasi akan lebih mudah dan lebih bisa diandalkan daripada menggunakan teknik mencatat tradisional. Selain itu Mind Mapping adalah sistem penyimpanan, penarikan data dan akses yang luar biasa untuk perpustakaan raksasa dalam otak manusia yang mengesankan.Mind Mapping bertujuan membuat materi pelajaran terpola secara visual dan grafis yang akhirnya dapat membantu merekam, memperkuat, dan mengingat kembali informasi yang telah dipelajari. Mind Mapping adalah satu teknik mencatat yang mengembangkan gaya belajar visual.

Mind Mapping memadukan dan mengembangkan potensi kerja otak yang terdapat di dalam diri seseorang. Dengan adanya keterlibatan kedua belahan otak maka akan memudahkan seseorang untuk mengatur dan mengingat segala bentuk informasi, baik secara tertulis maupun secara verbal. Adanya kombinasi warna, simbol, bentuk dan sebagainya memudahkan otak dalam menyerap informasi yang diterima.

Mind Mapping yang dibuat oleh siswa dapat bervariasi pada setiap materi. Hal ini disebabkan karena berbedanya emosi dan perasaan yang terdapat dalam diri siswa setiap saat. Suasana menyenangkan yang diperoleh siswa ketika berada di ruang kelas pada saat proses belajar akan mempengaruhi penciptaan peta pikiran. Dengan demikian, guru diharapkan dapat menciptakan suasana yang dapat mendukung kondisi belajar siswa terutama dalam proses pembuatan Mind Mapping.

Proses belajar yang dialami seseorang sangat bergantung kepada lingkungan tempat belajar. Jika lingkungan belajar dapat memberikan sugesti positif, maka akan baik dampaknya bagi proses dan hasil belajar, sebaliknya jika lingkungan tersebut memberikan sugesti negatif maka akan buruk dampaknya bagi proses dan hasil belajar.

\section{Pemahaman Siswa}

Pemahaman berasal dari kata paham yang berarti mengerti, sedangkan menurut Tim KBBI (dalam Shodiq 2009:16) pemahaman adalah cara memahami atau memahamkan, sedangkan menurut Bloom dalam Utami munandar (dalam Shodiq 2009:16) pemahaman adalah kemampuan untuk mengingat dan menggunakan informasi tanpa perlu menggunakannya dalam situasi baru dan berbeda. Bloom juga mengemukakan bahwa pemahaman merupakan salah satu sasaran kognitif yang berbeda ditingkat kedua setelah pengetahuan dalam pemahaman, ketrampilan yang diharapkan adalah keterampilan menerjemahkan, menghubungkan, dan menafsikan.

Menurut Heruman (dalam Shodiq:2009:16) pemahaman konsep adalah pembelajaran lanjutan dari pemahaman konsep yang bertujuan agar siswa lebih memahami suatu konsep. Heruman juga mengatakan bahwa pemahaman konsep terdiri atas dua pengertian, pertama merupakan kelanjutan dari pembelajaran penanaman konsep lam satu pertemuan, kedua pembelajaran pemahaman konsep di lakukan pada pertemuan yang berbeda tetapi masih merupakan kelanjutan dari pemahaman konsep pada pertemuan tersebut, penanaman konsep di anggap sudah di sampaikan pada pertemuan sebelumnya.

Sedangkan Sardiaman (dalam Shodiq 2009:16;17) mengatakan bahwa pemahaman atau comprehension dapat diartikan menguasai sesuatu denagn pikiran, karena itu belajar berarti harus mengerti secara mental makna dan filosofisnya maksud dari implikasinya dan aplikasi-aplikasinya, sehingga menyebabkan siswa dapat memahami suatu situasi. 
Dalam belajar, unsur pemahaman itu tidak dapat di pisahkan dari unsur-unsur psikologis yang lain: yaitu motivasi, konsentarsi, dan reaksi. Siswa sebagai subjek belajar dapat menggembangkan fakta-fakta, ide-ide, dan skill. Kemudian dengan unsur organisasi subjek belajar dapat menata dan menemukan hal-hal tersebut secara bersama menjadi suatu pola yang logis, karena mempelajari sejumlah data sebagaimana adanya, secara berangsurangsur subjek belajar mulai memahami arti dan implikasinya dari persoalan keseluruhan. Pemahaman berarti tidak sekedar harus tetapi juga menghendaki agar subjek belajar memanfaatkan bahan-bahan yang telah di pahami kalau sudah demikian belajar akan lebih mendasar, tetapi dalam kenyatannya banyak parasubjek disekolah-sekolah yang merupakan unsur comprehension. misalnya: banyak yang terjadi bahwa para pelajar melakukan belajar pada malam harimenjelang akan adanya ujian pada pagi harinya. Tetapi jika ditanya pada dua atau tiga hari kemudian, mengenai apa yang dipelajatinya kebanyakan sudah lupa, hal ini menunjukkan subjek belajar atau para siswa itu tidak memiliki perekatpemahaman yang kuat untuk menginternalisasi bahan-bahan yang dipelajari kedalam suatu konsep atau pengertian secara menyeluruh.

Sardiman (dalam Shodiq : 2009:18) menegaskan bahwa pemahaman bersifat dinamis dengan isi, diharapkan pemahaman akan bersifat kreatif, pemahaman akan menghasilkan imajinasi dan pikiran yang tengan, apabila subjek belajar atau siswa benar-benar memahaminya maka akan siap memerima jawaban yang pasti atas pertanyaan atau berbagai masalah dalam belajar.

Sementara itu Bloom dan Winkel (dalam Shodiq 2009:17;18) memasukkan pemahaman dalam ranah kognitif, pemahaman mencakup kemampuan untuk menangkap makna dan arti dari bahan yang di pelajari. Kemampuan pemahaman dapat diukur berdasarkan beberapa kata kerja operasional yaitu: membandingkan, mengidentifikasi, merinci, menghitung, mengubah, meguraikan, membedakan, mendiskusikan, memberi contoh, menerangkan, mengemukakan, merangkum, menjabarkan dsb. Siswa di pandang telah memiliki pemahaman tentang suatu hal dapat di tunjukkan dengan kemampuan siswa seperti contoh-contoh pada kata operasional di atas.

\section{METODOLOGI}

Penelitian ini termasuk jenis Penelitian Tindakan Kelas (PTK) atau di sebut dengan Classroom Action Research, adalah penelitian yang bertujuan untuk memperbaiki mutu proses dan hasil pembelajaran di kelas, sehingga dapat meningkatkan pemahaman, keaktifan, dan prestasi belajar siswa. Sesuai dengan jenis penelitian yaitu penelitian tindakan kelas, maka penelitian menggunakan model penelitian tindakan dari Kemmis dan Taggart (Wiriaatmadja:2008:66) yang berbentuk siklus dari empat tahap yaitu : perencanaan, pelaksanaan tindakan, observasi, dan refleksi.

Sumber data penelitian adalah siswa kelas IV MI Mambaul Ulum TegalgondoKarangploso Malang sejumlah 17 siswa, terdiri dari 5 siswa perempuan dan 12 siswa laki-laki. Bersama peneliti sebagai guru mata pelajaran, sebagai observer dan berkolaborasi dengan guru mata pelajaran selama kegiatan pembelajaran PKn yang di fokuskan pada peningkatan pemahaman siswa tentang sistem pemerintahan berlangsung.

Teknik ini digunakan untuk mengumpulkan data tentang gejala-gejala yang ada pada proses pembelajaran, keaktifan siswa dalam bertanya, kemauan dan kemampuan siswa dalam menanggapi pertanyaan, kerjasama dalam diskusi 
kelompok dan kemampuan dalam menggunakan media dalam pembelajaran dan Tes digunakan untuk mengumpulkan data tentang kemampuan siswa berupa soalsoal pada materi sistem pemerintahan dan hasil karya pembuatan peta konsep sistem pemerintahan.

Teknik analisa data yang digunakan dalam penelitian adalah :Teknik ini digunakan untuk menganalisis data tentang : keaktifan siswa yang dikumpulkan melalui cek list, kemampuan menguasai materi yang dinyatakan dalam bentuk skor melalui ulangan harian (tes), dan unjuk kerja (hasil karya) secara kelompok.

Menurut Purwanto (2000:103) untuk menafsirkan tingkat pemahaman siswa digunakan kriteria sebagai berikut:

Tabel:

Kriteria Tingkat Pemahaman Siswa

\begin{tabular}{|c|c|c|c|}
\hline $\begin{array}{c}\text { Tingkat } \\
\text { Pemahaman }\end{array}$ & Nilai & Bobot & Predikat \\
\hline $100 \%-85 \%$ & A & 4 & Sangat Baik \\
\hline $85 \%-75 \%$ & B & 3 & Baik \\
\hline $75 \%-60 \%$ & C & 2 & Kurang \\
\hline $60 \%-54 \%$ & D & 1 & $\begin{array}{c}\text { Sangat } \\
\text { Kurang }\end{array}$ \\
\hline $54 \%-0 \%$ & E & 0 & $\begin{array}{c}\text { Sangat } \\
\text { Kurang } \\
\text { sekali }\end{array}$ \\
\hline
\end{tabular}

$$
\text { Nilai }=\frac{\text { skor perolehan }}{\text { skor maksimal }} \times 100 \%
$$

Perencanaan tindakan lanjut dari siklus satu dilaksanakan apabila hasil perbaikan yang diharapkan belum tercapai pada siklus1, maka perlu langkah lanjutan pada siklus 2, siklus 3 dan seterusnya. sampai hasil yang di inginkan dapat tercapai. Satu siklus kegiatan merupakan kesatuan dari kegiatan perumusan masalah, perencanaan tindakan, pelaksaan tindakan, observasi dan interprestasi serta analisis data dan refleksi, banyak siklus tidak dapat diterapkan dan perlu dibuatkan kriteria keberhasilan.
Berdasarkan petunjuk pelaksanaan belajar mengajar pada Kurikulum Tingkat Satuan Pendidikan 2006 (Depdiknas, 2006) yaitu seorang siswa telah tuntas belajar mencapai skor $70 \%$ atau nilai 70 , dan kelas disebut tuntas belajar bila dikelas tersebut terdapat $85 \%$.

Adapun kriteria ketuntasan minimal (KKM) yang ada di MI Mambaul Ulum adalah sebagai berikut: Kriteria ketuntasan minimal $(\mathrm{KKM})$ individu $=70$ dan Kriteria ketuntasan minimal $(\mathrm{KKM})$ kelas $=80 \%$

\section{HASIL DAN PEMBAHASAN}

\section{Hasil Penelitian}

Pada tahap ini, peneliti mengidentifikasi permasalahan dan menganalisis masalah dalam pembelajaran mata pelajaran PKn dalam materi pokok sistem pemerintahan kelas IV MI Mambaul Ulum Tegalgondo Karangploso Malang. Peneliti mengumpulkan informasi yang lebih mendalam melalui diskusi dengan guru mata pelajaran.

Sebelum memulai kegiatan pembelajaran terlebih dahulu peneliti mengadakan pre tes kepada siswa kelas IV dengan 20 soal terdiri dari 10 pilihan ganda dan 10 soal essay. Kegiatan pre tes ini dilakukan dengan tujuan untuk mengetahui penguasaan konsep siswa terhadap materi sistem pemerintahan. Dari hasil pre tes dapat diketahui hanya beberapa siswa yang sudah menguasai materi sistem pemerintahan, seperti terlihat pada tabel berikut ini :

\begin{tabular}{|c|c|c|c|c|}
\hline No & Nilai & $\begin{array}{c}\text { Freku- } \\
\text { ensi }\end{array}$ & $\begin{array}{c}\text { Persenta- } \\
\text { si }\end{array}$ & Kategori \\
\hline 1. & $\begin{array}{c}85- \\
100\end{array}$ & 2 & $12 \%$ & $\begin{array}{c}\text { Baik } \\
\text { sekali }\end{array}$ \\
\hline 2. & $85-75$ & 4 & $24 \%$ & Baik \\
\hline 3. & $75-60$ & 1 & $5,0 \%$ & Cukup \\
\hline 4. & $0-60$ & 10 & $59 \%$ & Kurang \\
\hline
\end{tabular}




\begin{tabular}{|l|l|l|}
\hline Jumlah & 17 & $100 \%$ \\
\hline
\end{tabular}

Dari tabel di atas perolehan pre tes diketahui bahwa anak yang sudah memahami materi dengan perolehan nilai di atas 70 dengan kategori baik sekali dan baik sejumlah 6 (enam) anak. Sedangkan siswa yang masih belum tuntas dan termasuk dalam kategori cukup dan kurang sejumlah 11 anak. Berdasarkan pre tes ini maka peneliti menginginkan peningkatan pemahaman konsep dapat meningkat, salah satunya dengan cara menerapkan metode Mind Mappingpada kegiatan siklus 1.

Hasil pada siklus I tingkat pemahaman kegiatan kelompok dengan menggunakan metode M2M (Mind Mapping) pada siklus 1 (satu) adalah $50 \%$ atau sejumlah 2 (dua) kelompok yang memperoleh nilai baik. kelompok yang memperoleh nilai cukup dan kurang adalah $50 \%$. hal ini menunjukkan bahwa siswa kurang memahamipenjelasan dari guru dan kurang memperhatikan pembelajaran yang sudah dilakukan seperti pada tabel berikut:

\section{Tabel}

Hasil Kegiatan Kelompok dengan

Menggunakan

Mind MappingPada Siklus 1

\begin{tabular}{|c|c|c|c|c|}
\hline No. & $\begin{array}{c}\text { Nama } \\
\text { kelompok }\end{array}$ & $\begin{array}{c}\text { Pemaha } \\
\text { man } \\
\text { materi }\end{array}$ & $\begin{array}{c}\text { Kreatifan } \\
\text { dalam } \\
\text { membuat } \\
\text { bagan }\end{array}$ & $\begin{array}{c}\text { Skor } \\
\text { total }\end{array}$ \\
\hline 1. & Satu & 25 & 55 & 80 \\
\hline 2. & Dua & 20 & 55 & 75 \\
\hline 3. & Tiga & 25 & 60 & 85 \\
\hline 4. & Empat & 15 & 50 & 65 \\
\hline
\end{tabular}

Keterangan :
1. Baik sekali
:0 kelompok
2. Baik
: 2 kelompok
3. Cukup
: 1 kelompok
4. Kurang
: 1 kelompok

Tabel

Hasil Rekaman Pemahaman Mind

MappingSiklus 1

\begin{tabular}{|c|c|c|}
\hline No & Uraian & Presentasi \\
\hline 1. & Baik sekali & $0 \%$ \\
\hline 2. & Baik & $50 \%$ \\
\hline 3. & Cukup & $25 \%$ \\
\hline 4. & Kurang & $25 \%$ \\
\hline
\end{tabular}

Tingkat pemahaman kegiatan kelompok dengan menggunakan metode M2M (Mind Mapping) pada siklus 1 (satu) adalah $50 \%$ atau sejumlah 2 (dua) kelompok yang memperoleh nilai baik. kelompok yang memperoleh nilai cukup dan kurang adalah $50 \%$. hal ini menunjukkan bahwa siswa kurang memahamipenjelasan dari guru dan kurang memperhatikan pembelajaran yang sudah dilakukan.

Tingkat pemahaman kegiatan kelompok dengan menggunakan metode Mind Mappingpada siklus 2 adalah $50 \%+$ $25 \%=75 \%$, hasil ini menunjukkan bahwa pemahaman siswa mengalami peningkatan lebih baik dari siklus 1. Perolehan nilai yang baik sekali ada 2 kelompok, baik 1 kelompok dan cukup 1kelompok. Hal ini menunjukkan bahwa ada peningkatan pemahaman siswa pada pembelajaran yang telah dilaksanakan, sehingga hasil evaluasi pada siklus 2 juga mengalami peningkatan secara signifikan. Hasil evaluasi akhir kegiatan pembelajaran siswa pada siklus 1 menunjukkan pemahanan konsep yang diperolah siswa selama pembelajaran berlangsung masih rendah. Pada akhir kegiatan di adakan refleksi berupa tanya jawab tentang materi yang sudah dibahas dan memberikan latihan soal untuk mengetahui tingkat pemahaman siswa pada 
akhir pembelajaran. Pada evaluasi siklus 2 hasil yang diperolah siswa sudah membaik dari pada hasil pada siklus 1 , mereka sudah begitu memahami tentang materi sistem pemerintahan yang ada di Indonesia, hal tersebut menandakan bahwa siswa sudah ada peningkatan dalam memahami konsep sistem pemerintahan.

Pelaksanaan pembelajaran pada siklus 2 lebih terarah dan suasana kelas menjadi lebih terkendali dengan siswa dapat bekerjasama dengan baik. Hal tersebut dapat dilihat semakin meningkat pemahaman siswa terhadap materi yang disampaikan oleh guru ketuntasan belajar meningkat dari silus 1dan siklus 2 yaitu masing-masing kelompok mendapatkan presentasi $50 \%$ dan $75 \%$, sedangkan untuk evaluasi indivindu memperoleh presentase $59 \%$ dan $82 \%$. Pada siklus 2 (dua) ketuntasan belajar siswa secara klasikal dan individu telah tercapai. seperti pada tabel berikut:

\section{Tabel}

Hasil kegiatan kelompok dengan

\section{menggunakan}

\section{Mind Mapping pada siklus 2}

\begin{tabular}{|c|c|c|c|c|}
\hline No. & $\begin{array}{c}\text { Nama } \\
\text { kelom } \\
\text { pok }\end{array}$ & $\begin{array}{c}\text { Pemaham } \\
\text { an materi }\end{array}$ & $\begin{array}{c}\text { Kreatifan } \\
\text { dalam } \\
\text { membuat } \\
\text { bagan }\end{array}$ & $\begin{array}{c}\text { Skor } \\
\text { total }\end{array}$ \\
\hline 1. & Satu & 35 & 45 & 80 \\
\hline 2. & Dua & 40 & 45 & 85 \\
\hline 3. & Tiga & 40 & 55 & 90 \\
\hline 4. & Empat & 35 & 35 & 70 \\
\hline
\end{tabular}

Keterangan :

1. Baik sekali : 2 Kelompok

2. Baik : 1 Kelompok

3. Cukup : 1 Kelompok

4. Kurang : 0 Kelompok
Tabel

Hasil rekaman pemahaman Mind Mapping Siklus 2

\begin{tabular}{|c|c|c|}
\hline No & Uraian & Presentase \\
\hline 1. & Baik sekali & $50 \%$ \\
\hline 2. & Baik & $25 \%$ \\
\hline 3. & Cukup & $25 \%$ \\
\hline 4. & Kurang & $0 \%$ \\
\hline
\end{tabular}

Adanya peningkatan pemahaman siswa karena adanya pembagian tugas yang merata serta kerja sama antar setiap kelompok. Setiap anggota mempunyai kesempatan yang sama dalam memahami materi yang diberikan oleh guru. Siswa dapat berkerja sama mengerjakan soal yang diberikan oleh guru dalam pembuatan Mind Mapping yang sesuai dengan materi yang telah diberikan. Setiap akhir pembelajaran guru menginformasikan untuk mempelajari materi berikutnya, sehingga siswa termotivasi untuk belajar. Selain itu siswa juga memahami apa yang dimaksudkan dan di inginkan oleh guru dengan metode M2M (Mind Mapping) yang didukung dengan media bagan peta konsep.

Peningkatan secara signifikan perolehan nilai kelompok pada siklus 1 dengan siklus 2. Pada siklus 1 terdapat 3kelompok yang tuntas belajar dan 1 kelompok yang masih belum tercapai, sedangkan pada siklus 2 sudah tuntas semua tetapi masih ada yang memperoleh cukup.

Darirekaman hasil evaluasi akhir pra siklus, siklus 1, siklus 2 dapat diketahui bahwa hasil evaluasi pre test yang telah tuntas hanya 7 siswa atau $42 \%$, sedangkan yang tidak tuntas 10 siswa atau $59 \%$. Hasil siklus 1 terdapat 10 siswa atau $59 \%$ yang 
tuntas dan 7 siswa atau $41 \%$ yang tidak tuntas. Siklus 2 mengalami peningkatan sebesar $20 \%$ dari siklus 1, dalam siklus 2 terdapat 14 siswa atau $82 \%$ yang tuntas belajar dan 3 siswa atau $18 \%$ yang tidak tuntas, dari rangkaian kegiatan pembelajaran yang dilakukan.

\section{Pembahasan}

\section{Pelaksanaan Metode Mind Mapping}

Pelaksanaan pembelajaran dengan menggunakan metode Mind Mappingyang didukung oleh media bagan peta konsep dalam siklus 1masih kurang begitu sempurna karena kurang pemahanan yang diterima oleh siswa ketika guru menyampaikan tujuan pembelajaran kurang begitu jelas.

Pelaksanaan kegiatan diawali dengan membaca dan memperhatikan apa yang disampaikan oleh guru dengan melihat buku paket masing-masing mengenai sistem pemerintahan, setelah itu guru menempelkan media berupa bagan peta konsep tentang sistem pemerintahan, kemudian guru menjelaskan sedikit tentang sistem pemerintahan yang ada di Indonesia.

Kemudian guru membagi siswa dalam 4 kelompok dan mengerjakan soal yang diberikan oleh guru dengan menggunakan metode Mind Mapping sesuai dengan kreatifitas dan imajinasi antar kelompok. Setelah itu hasil kelompok di samapaikan di depan kelas serta menceritakan bagan imajinasi yang telah dibuat, dan kelomopok lain diminta untuk menaggapi hasil kelompok teman yang lain.

Hasil kegiatan pada siklus 1 dalam pembuatanMind Mappng karena membutuhkan waktu yang cukup lama untuk menyelesaikannya sehingga hasilnya tidak begitu sempurna siswa membuat bagan apa adanya sesuai dengan yang di inginkan.

Kegiatan pembelajaran metode Mind Mapping yang dilaksanakan pada siklus 2, siswa mulai mengerti tentang tugas yang harus dikerjakan, kegiatan membuat bagan peta konsep sistem pemerintahan dengan diberikan waktu yang cukup lama, sehingga siswa bebas mengkreasikan hasilnya dan juga guru memberikan contoh yang bagan yang berukuran besar, sehingga siswa lebih mudah untuk memahaminya.

Hasil Pada siklus 2 ini mengalami perbaikan yang cukup baik untuk pembelajaran menggunakan metode Mind Mapping, sehingga bisa dilakuakan untuk pembelajaran berikutnya dengan lebih baik lagi dan mempertahankan pelaksanaan yang sudah baik.

\section{Ketuntasan Pemahaman Siswa}

Melalui hasil penelitian ini menunjukkan bahwa menerapkan metode Mind Mapping memiliki dampak positif dalam meningkatkan pemahaman siswa, dengan penerapan metode Mind Mappingmaka anak akan muncul kreatifitas dan imajinasi anak dalam membuat bagan peta konsep yang telah ditentukan dengan bantuan contoh bagan peta konsep.

Hasil bagan yang dibuat pada siklus 1 belum begitu sempurna karena siswa masih belum mengerti tentang pembuatan Mind Mappingkarena guru kurang begitu jelas dalam menerangkan pembuatan Mind Mapping, karena antar kelompok masih belum mengerti apa yang harus dikerjakan dan masing-masing anak mempunyai imajinasi sendiri-sendiri sehingga hasil yang dikerjakan tidak begitu maksimal.

Pada siklus 2 pembuatan bagan sudah begitu menarik karena siswa sudah mengerti apa yang dimaksud dengan pembuatan bagan peta konsep dengan kreatifitas dan imjinasi anak, sehingga antar kelompok berkerjasama agar apa yang dihasilkan dapat menarik dan menghasilkan karya yang baik.

Hasil evaluasi akhir kegiatan pembelajaran siswa pada siklus 1menunjukkan pemahanan konsep yang diperolah siswa selama pembelajaran berlangsung masih rendah. Pada akhir kegiatan di adakan refleksi berupa tanya jawab tentang materi yang sudah dibahas 
dan memberikan latihan soal untuk mengetahui tingkat pemahaman siswa pada akhir pembelajaran.

Pada evaluasi siklus 2 hasil yang diperolah siswa sudah membaik dari pada hasil pada siklus 1, mereka sudah begitu memahami tentang materi sistem pemerintahan yang ada di Indonesia, hal tersebut menandakan bahwa siswa sudah ada peningkatan dalam memahami konsep sistem pemerintahan.

Pelaksanaan pembelajaran pada siklus 2 lebih terarah dan suasana kelas menjadi lebih terkendali dengan siswa dapat bekerjasama dengan baik. Hal tersebut dapat dilihat semakin meningkat pemahaman siswa terhadap materi yang disampaikan oleh guru ketuntasan belajar meningkat dari silus 1dan siklus 2 yaitu masing-masing kelompok mendapatkan presentasi $50 \%$ dan $75 \%$, sedangkan untuk evaluasi indivindu memperoleh presentase $59 \%$ dan $82 \%$. Pada siklus 2 (dua) ketuntasan belajar siswa secara klasikal dan individu telah tercapai.

Kemampuan Guru dalam Mengelolah Pembelajaran

Berdasarkan analisis data, diperoleh dari aktivitas siswa dalam proses belajar mengajar dalam setiap siklus mangelami peningkatan, hal ini berdampak positif terhadap peningkatan pemahan siswa yaitu ditunjukkan denga nilai rata-rata siswa dalam kelompok maupun individu dalam evaluasi akhir pelajaran pada setiap siklus yang mengalami peningkatan.

Perbaikan yang dilaksanakan pada siklus 2 merupakan hasil dari evaluasi terhadap kegiatan pembelajaran yang telah dilaksanakan pada siklus 1. Adanya perubahan dalam beberapa kegiatan pembelajaran membuat siswa dapat dikondisikan dengan tertib dan teratur dalam melaksanakan kegiatan pembelajaran.

Kegiatan awal pembelajaran yang dilaksanakan oleh guru pada siklus 1belum mampu mengarahkan siswa ke materi yang akan di pelajari, siswa tidak memperhatikan guru dan membuat gaduh dengan menggangu teman yang lainnya, sehingga guru masih kurang jelas dalam menyampaikan materi serta langkah-langkah kegiatan yang akan dilaksanakan.

Pada siklus 2 guru menjelaskan kegiatan yang harus dilaksanakan dan aturan-aturan kerja kelompok agar setiap kelompok dapat bekerja sama dengan baik, penyampaikan langkah kegiatan yang dilakukan oleh guru lebih jelas sehingga dalam siklus 2 sebagian kelompok siswa dapat bekarja mandiri dengan kerjasama antar anggota kelompok.

Metode Mind Mapping dengan media bagan peta konsep digunakan untuk membantu siswa dalam mencapai tujuan pembelajaran pada siklus 1 telah mengalami perubahan. Pada siklus 1siswa membuat bagan peta sistem pemerintahan secara berkelompok belum begitu memahami tugas yang harus dikerjakan dalam kelompok. Perbaikan yang dilakukan pada siklus 2 membuat siswa lebih mudah dalam membuat bagan peta konsep sistem pemerintahan menjadi terarah dan terkendali dan setiap siswa dapat bekerjasama dengan baik.

Pengaturan waktu dalam pembuatan bagan peta konsep mengalami perbaikan sehingga siswa dapat bekerjasama dengan waktu yang telah ditentukan. Hal tersebut disebabkan guru terus memberikan motivasi kepada siswa agar dapat mempergunakan waktu sebaik-baiknya sehingga dapat mengerjakan tugas tepat waktu.

\section{PENUTUP}

Berdasarkan hasil penelitian yang dilaksanakan menunjukkan adanya peningkatan pemahaman siswa pada proses pembelajaran, Peningkatan proses belajar berakibat positif pada pemahaman siswa yang mengalami peningkatan setiap siklusnya. Pada Siklus 1 hasil kegiatan kelompok pembuatan Mind 
Mappingdiperoleh $50 \%$ dan pada siklus 2 meningkat menjadi $75 \%$, hal ini menunjukkan adanya peningkatan pemahaman siswa tentang sistem pemerintahan melalui kegiatan kelompok. Sedangkan hasil evaluasi individu pada akhir pembelajaran (siklus), pada siklus 1 diperoleh nilai $59 \%$ dan pada siklus 2 meningkat menjadi $82 \%$, hal ini menunjukkan adanya peningkatan pemahaman siswa tentang sistem pemerintahan melalui latihan soal pada akhir pembelajaran. Jadi dapat disimpulkan bahwa melalui metode Mind Mapping pemahaman siswa pada mata pelajaran PKn tentang sistem pemerintahan mengalami peningkatan yang signifikan dari siklus 1 ke siklus 2 .

\section{DAFTAR PUSTAKA}

Djamarah, Syaiful Bahri. 2002. Strategi Belajar Mengajar. Rineka Cipta: Jakarta

Mulyasa. 2010. Praktik Penelitian Tindakan Kelas. PT. Remaja Rosdakarya: Bandung

Kurniawati. Dhida Dwi. 2010.Pengaruh Metode Mind Mapping Dan Keaktifan Belajar Siswa Terhadap Prestasi Belajar Ilmu Pengetahuan Sosial Pada Siswa Kelas VIII Sekolah Menengah Pertama Muhammadiyah 5 Surakarta Tahun Pelajaran 2009 / 2010. FKIP Universitas Muhammadiyah Surakarta

Purwanto. 2000. Evaluasi Hasil Belajar. Pustaka Pelajar: Yogyakarta.

Shodiq. Ahmad. 2009. Peningkatan Pemahaman Siswa Tentang Alat Gerak Hewan Melalui Media Gambar dan Hewan Nyata Kelas 2
SDN Sirnoboyo Kecamatan Benjeng Kabupaten Gresik. FKIP UMM

Wiriaatmadja Rochiati. 2008. Metode Penelitian Tindakan Kelas. PT. Remaja Rosdakarya. Bandung

Undang-Undang RepublikIndonesia Nomor 20 Tahun 2003 Tentang Sistem Pendidikan Nasional. 